\title{
Zinc deficiency syndrome in a British youth with cystic fibrosis
}

A syndrome of dwarfism and retarded sexual development among Iranian and Egyptian teenage boys has been shown to be due to zinc deficiency. ${ }^{1}$ A British patient with cystic fibrosis and nephrotic syndrome showed growth retardation and hypogonadism, associated with low plasma zinc concentrations.

\section{Case history}

The patient was diagnosed as having cystic fibrosis at 5 years of age, and treated conventionally with antibiotics and pancreatic enzymes. The next year he had an episode of haematuria and proteinuria without oedema or hypertension. At 17 years he was referred to the cystic fibrosis clinic with depression, chronic cough, green sputum, recurrent abdominal pain, and steatorrhoea. He was prepubertal, with height and weight well below the 3 rd centiles. He had considerable finger clubbing, dry skin, bilateral crackles at the lung bases, liver enlargement, and a normal blood pressure. His sweat electrolyte and urine protein, serum alkaline phosphatase, and plasma cholesterol concentrations were raised; the serum albumin concentration was decreased. Chest $x$-ray film showed moderately severe changes of cystic fibrosis; an intravenous pyelogram showed a normal renal tract and pancreatic calcification. Renal biopsy was refused.

At 18 years 4 months he was further investigated for delayed puberty and short stature. His bone age was 11 years 8 months. Growth hormone response to levodopa was normal; the results of thyroid function tests were normal. Concentrations of testosterone were $72.5 \mathrm{mg} / 100 \mathrm{ml}$; of $\mathrm{LH}$ and FSH normal; of serum alkaline phosphatase over $120 \mathrm{IU} / 1$; and of SHBD $645 \mathrm{IU} /$ 1. Rectal biopsy showed no evidence of amyloid disease. Five months later, his plasma zinc concentration was only $3 \cdot 45-3.75 \mu \mathrm{mol} / 1$ (23-25 $\mu \mathrm{g} 100 \mathrm{ml}$ ) on three occasions (normal 70-160). The urine zinc concentration was raised, $13.8 \mu \mathrm{mol} / 24 \mathrm{~h}(0.9 \mathrm{mg} / 24 \mathrm{~h}$ ) (normal 0.76-7.6 $\mu \mathrm{mol} / 1 ; 0.05-0.5$ $\mathrm{mg} / 24 \mathrm{~h}$ ) and hair zinc concentration low, $110 \mathrm{ppm}$ (mean adult value $180 \pm 4$, child $153 \pm 5$ ). Intravenous injection of $10 \mu \mathrm{Ci}{ }^{51} \mathrm{Cr}$ chromic chloride produced a faecal loss of $9.5 \%$ in 96 hours (normal less than $1 \%$ ), indicating protein-losing enteropathy.

Treatment with oral zinc sulphate $180 \mathrm{mg}$ /day was then started, the patient himself increasing the dose on several occasions. After six months there was slight genital growth and a few pubic hairs appeared. He developed oedema, ascites, and increased diarrhoea. The serum albumin concentration was $16 \mathrm{~g} / \mathrm{l}$. Diuresis was induced with frusemide and intravenous salt-free albumin, and control of oedema maintained with intermittent frusemide. His zinc balance remained poor, plasma values of $5.4 \mu \mathrm{mol} / 1(35 \mu \mathrm{g} / 100 \mathrm{ml})$ and hair zinc of $110 \mathrm{ppm}$ being recorded.

At 19 years 10 months renal biopsy showed features of focal proliferative glomerulonephritis. By then he was taking $1200 \mathrm{mg}$ of zinc sulphate daily. His genitalia were enlarging and his bone age had advanced to 14 years. This progress has been maintained. At 20 years application of testosterone cream for two months increased the growth of pubic hair. His plasma zinc concentrate was then $15.9 \mu \mathrm{mol} / 1(104 \mu \mathrm{g} / 100 \mathrm{ml})$; that of testosterone $33.9 \mu \mathrm{mol} / 1(980 \mathrm{mg} / 100 \mathrm{ml})$. At 21 years he has crossed the 3rd centile for height and his genital development is 3 on the Tanner scale (see fig).

\section{Discussion}

Several factors probably contributed to the patient's zinc deficiency, which is among the most severe on record. Firstly, the cystic fibrosis.

$\begin{array}{llllll}\text { Genitalia (Tannergrade) } & 1 & 1 & 1-2 & 2 & 3 \\ \text { Plasma zinc ( } \mu \mathrm{mol} / 1) & 23 & 35 & 136^{*} & 104\end{array}$

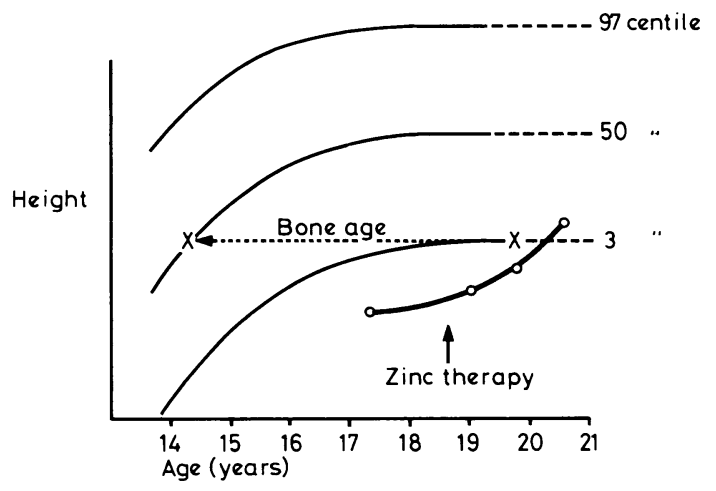

Height, genital development, and zinc concentrations. Conversion: $S I$ to traditional units-Zinc: $1 \mu \mathrm{mol} / 1 \approx$ $6.5 \mu \mathrm{g} / 100 \mathrm{ml}$.

*Serum concentration
Children with cystic fibrosis often have slightly low plasma zinc concentrations, particularly those with growth retardation. ${ }^{2} \mathrm{Zinc}$ absorption may be facilitated by a zinc-binding ligand secreted by the pancreas, ${ }^{3}$ which is possibly deficient in cystic fibrosis. Secondly, zinc loss in the urine-which occurs with proteinuria ${ }^{3}$ in chronic liver disease, and in chronic infections. The zinc deficiency observed in inflammatory bowel disease is a likely consequence of other protein-losing enteropathies. ${ }^{4}$ The final factor might be treatment with frusemide, which is associated with increased zincuria, ${ }^{5}$ but our patient was zinc-deficient before any diuretic treatment.

The combination of cystic fibrosis and nephrotic syndrome appears to be fortuitous, and undoubtedly adverse effects on zinc homoeostasis were cumulative. Nevertheless, zinc deficiency should be considered when somatic and sexual growth failure occur in patients with cystic fibrosis.

We thank Professor A W Asscher and Dr J Picton Thomas for their help in the management of this patient. JGY was supported by a grant from the Cystic Fibrosis Research Trust during part of this case study.

Correspondence should be addressed to Dr J A Dodge, Department of Child Health, University Hospital of Wales, Cardiff CF4 4XW.

${ }^{1}$ Prasad, A S, et al, Archives of Internal Medicine, 1963, 111, 407.

${ }^{2}$ Halsted, J A, and Smith, J C, Lancet, 1970, 1, 322.

${ }^{3}$ Evans, G W, in Trace Elements in Human Health and Disease, ed A S Prasad. New York, Academic Press, 1976.

- Sanstead, H H, Vo-Khactu, K P, and Solomons, N, in Trace Elements in Human Health and Disease, ed A S Prasad, p 137. New York, Academic Press, 1976.

${ }^{5}$ Steele, T H, fournal of Laboratory and Clinical Medicine, 1971, 78, 1019.

(Accepted 20 September 1977)

Department of Child Health, Welsh National School of Medicine, University Hospital of Wales, Cardiff

J A DODGE, FRCP, DCH, reader

J G YASSA, $\mathrm{MB}, \mathrm{DCH}$, research registrar

\section{Preliminary results of a twenty-year follow-up of a random sample of an industrial town}

During the 1950s the Medical Research Council's Pneumoconiosis Unit carried out several surveys of complete, or of random samples from, communities in England and Wales. Sufficient time has elapsed to follow up some of these communities 20 years later. The results of the first attempt in the Rhondda Fach have already been published. ${ }^{1}$ Inter alia, this drew attention to the lack of a negative correlation between $x$-ray category of simple pneumoconiosis and survival rates. This second 20-year follow-up had, as one of its objectives, to confirm or refute this important finding.

\section{Material, methods, and results}

The original survey was carried out in November 1954 and results published in $1956 . .^{2}$ Out of a sample of 245 men aged 55-64 living in Leigh, Lancs, $221(90.2 \%)$ were examined; five were excluded for various reasons.

20-Year survival rates of Leigh men aged 55-64 by two methods of analysis

\begin{tabular}{|c|c|c|c|c|c|c|c|}
\hline \multirow{2}{*}{\multicolumn{2}{|c|}{ Group }} & \multicolumn{3}{|c|}{$\begin{array}{l}\text { All members of } \\
\text { random sample in } 1954\end{array}$} & \multicolumn{3}{|c|}{$\begin{array}{l}\text { All those not exposed } \\
\text { to serious industrial } \\
\text { respiratory hazards, } \\
\text { other than coal dust }\end{array}$} \\
\hline & & No & $\begin{array}{c}\text { No } \\
\text { surviving }\end{array}$ & $\begin{array}{c}\% \\
\text { survival }\end{array}$ & No & $\begin{array}{c}\text { No } \\
\text { surviving }\end{array}$ & $\begin{array}{c}\% \\
\text { survival }\end{array}$ \\
\hline $\begin{array}{l}\text { Non-miners } \\
\text { Miners and ex-miners } \\
\text { Category } 0 \text {. } \\
\text { Category } 1,2,3 \ldots \\
\text { Categories } 0,1,2,3 \\
\text { Category } \mathrm{A}, \mathrm{B}, \mathrm{C}\end{array}$ & $\begin{array}{l}\cdots \\
\cdots \\
\cdots \\
\cdots\end{array}$ & $\begin{array}{r}84 \\
101 \\
21 \\
122 \\
10\end{array}$ & $\begin{array}{r}29 \\
30 \\
7 \\
37 \\
2\end{array}$ & $\begin{array}{l}34 \cdot 5 \\
29 \cdot 7 \\
33 \cdot 3 \\
30 \cdot 3 \\
20 \cdot 0\end{array}$ & $\begin{array}{r}49 \\
64 \\
17 \\
81 \\
4\end{array}$ & $\begin{array}{r}16 \\
21 \\
5 \\
26 \\
1\end{array}$ & $\begin{array}{l}32 \cdot 7 \\
32 \cdot 8 \\
29 \cdot 4 \\
32 \cdot 1) \\
25 \cdot 0\end{array}$ \\
\hline All miners and ex-mine & & 132 & 39 & $29 \cdot 5$ & 85 & 27 & $31 \cdot 8$ \\
\hline
\end{tabular}


Of the remaining 216, all have been followed up for twenty years, in the sense that we have good evidence whether they are alive or dead.

The results are summarised in the table. These in general confirm the results from the Rhondda Fach in that the survival rates of those with simple pneumoconiosis are similar to those with category 0 for both all miners and ex-miners and those not exposed to other industrial respiratory hazardsin particular, exposure to cotton dust. The numbers in the latter group are much smaller but show exactly the same trend. There are two other points of interest. Firstly, the similarity between the survival rates of the non-miners and those miners and ex-miners with categories $0,1,2$, and 3 (this is very different from the findings in the Rhondda Fach, ${ }^{1}$ where the survival rates of those with these categories were considerably lower than those of the non-miners in this age group). Secondly, the survival rates of the non-miners and all miners and ex-miners, including those with progressive massive fibrosis (Categories A, B, and C), are reasonably comparable.

\section{Discussion}

Although the numbers are relatively small and confined to one age group, they represent the results of a $100 \%$ follow-up. In general, they confirm the findings in the Rhondda Fach that miners and exminers with simple pneumoconiosis survive as well as those with category 0 . It must, however, be remembered that we are ignorant how the miners were selected from the general population, and how selective and how large the migration of ex-miners out of this area has been, before the survey took place. It must also be emphasised that mortality is not necessarily associated with disability.

The similarity between the survival rates of non-miners and miners and ex-miners with category 0 , in contrast to the findings in the Rhondda Fach, ${ }^{1}$ is striking. This highlights the importance of survival studies on a local basis in order to have a comparison group. Finally, the fact that all miners and ex-miners, including those with all categories of pneumoconiosis, survive in this age group nearly as well as the average of the population is of interest.

We are deeply indebted to Dr P H N Wood and the Arthritis Research Council's field team, who successfully traced the members of the random sample, and to Dr Ross Ullman who helped us trace one man who had emigrated to Australia.

\footnotetext{
${ }^{1}$ Cochrane, A L, British Medical fournal, 1973, 2, 532.
}

${ }^{2}$ Higgins, I T T, et al, British Medical fournal, 1956, 2, 904.

(Accepted 26 October 1977)

MRC Epidemiology Unit, Cardiff

A L COCHRANE, FRCP, FFCM, formerly director (now retired)

F MOORE, SRN, chief technician

\section{Unilateral short thumb associated with bleeding duodenal reduplication}

Intraluminal duodenal reduplications are uncommon and often undiagnosed during life. ${ }^{1}$ They take the form of protrusions of the duodenal wall, usually into the curve of the second part, and often cause problems due to obstruction of the lower end of the common bile duct or of the duodenal lumen itself. ${ }^{2}$ In some cases associated congenital abnormalities have been present. ${ }^{3}$ We report a patient who presented with massive bleeding and at operation was found to have the ampulla of Vater embedded in its wall. The patient was noted to have a unilateral short thumb.

\section{Case report}

A 41-year-old woman designer was admitted to a hospital in 1974 with a history of melaena for several days. The results of investigations including barium meal, barium enema, and endoscopy were negative. She was discharged in good health after a blood transfusion of 6 units. Two years later she again had melaena and a haemoglobin of $4.8 \mathrm{~g} / \mathrm{dl}$. Transfusion with 9 units of blood restored the haemoglobin to $12 \mathrm{~g} / \mathrm{dl}$. She had no history of having taken any drug or material which might have precipitated the bleeding, nor was there any history or family history relating to a bleeding diathesis. She had always been completely healthy and symptom free.

Systemic examination showed no abnormalities and rectal examination confirmed the presence of melaena. Her blood pressure was $120 / 70$ and the pulse rate 88 per minute in sinus rhythm. The distal phalanx of her right thumb was however noted to be extremely short. Barium meal again showed no abnormality, although the appearances at endoscopy suggested the presence of blood beyond the second part of the duodenum. The steady fall in her haemoglobin concentration over the next 72 hours suggested a steady ooze of blood. Selective mesenteric angiography was then performed but no abnormality identified.

At laparotomy both the large and small bowel were full of blood with no specific lesions identifiable. Segmental clamping afforded no further help but on advancing the nasogastric tube through the pylorus into the second part of the duodenum bright red blood was aspirated. A longitudinal duodenotomy was then performed and a cystic duplication of the duodenum demonstrated. This was wind-sock shaped and had numerous fenestrations in its wall, some of which were oozing blood. Excision of the reduplication was performed with care since it had been demonstrated that the common bile duct was opening into its wall (figure). The duct was carefully preserved and reimplanted into the normal duodenal wall. The patient's recovery was uneventful, and two years later she is well with no further evidence of bleeding.

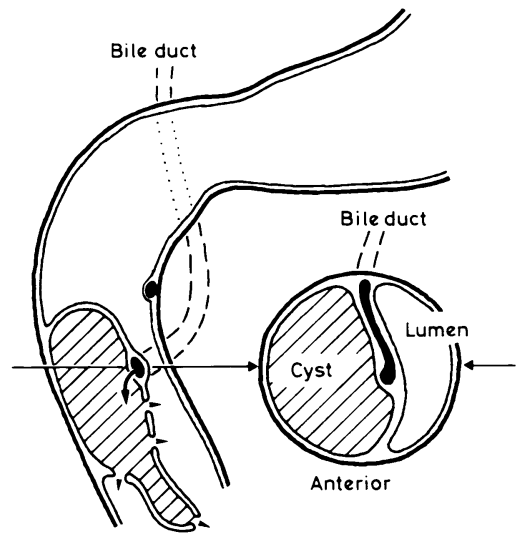

Diagram of cystic reduplication of second part of duodenum with common bile duct opening into it. Fenestrations which were bleeding are indicated by small arrows.

\section{Comment}

Duodenal reduplications usually present with symptoms of upper gastrointestinal obstruction or of biliary obstruction. In rare instances they may produce pancreatitis ${ }^{4}$ or even perforate. ${ }^{5}$ It is extremely unusual for them to present with massive bleeding, though when this does occur it usually is superimposed on a long history of upper gastrointestinal symptomatology. In these cases pathological examination of the wall shows evidence of ulceration and occasionally even heterotopic gastric mucosa. The condition is probably congenital and as might be expected the existence of many congenital skeletal and cardiac abnormalities (arachnodactyly, vertebral anomalies, talipes equinus varus, atrial septal defect, and ventricular septal defect) has been recorded in association with duodenal reduplications. ${ }^{3}$ The $O$ identification of one such in a patient with upper gastrointestinal symptoms and more especially unexplained bleeding might provide a valuable diagnostic clue.

A clinical marker of a potential duodenal lesion would be extremely helpful for the surgeon, since an unidentified bleeding source in a $\mathrm{N}$ patient whose whole bowel is full of blood poses a major problem. N At the operation itself the additional relevant feature is the fairly $C$ common relationship of the reduplication to the common bile duct which should be carefully identified and preserved.

${ }^{1}$ Guerrier, H, and Turner, M, British fournal of Surgery, 1972, 59, 324.

${ }^{2}$ Basu, R, and Forshall, I, British fournal of Surgery, 1960, 47, 477.

3 Thompson, N, and Labou, F, Archives of Surgery, 1967, 94, 301.

4 Lawson, T, Digestive Diseases, 1974, 19, 673.

5 Dickinson, W, et al, American fournal of Surgery, 1971, 122, 418.

(Accepted 26 October 1977)

Department of Surgery, Hammersmith Hospital and the Roya Postgraduate Medical School, London W12 0HS

IRVIN M MODLIN, FRCS, FCS(SA), senior registrar (present address:

Department of Surgery, University of California, Los Angeles)

JOHN SPENCER, MS, FRCS, consultant surgeon 